\title{
Talent Management Practices as an Instrument for Stimulating Employees' Entrepreneurship
}

\begin{abstract}
Aneta Karasek*
Innovation constitutes a source of competitive advantage. Therefore, enterprises are interested in finding innovative solutions. Employees, and their entrepreneurship in particular, play a significant role in the process. Moreover, the literature of the subject highlights the significance of talented employees for innovative enterprises. It can also be observed that constituting elements of talents clearly correspond with characteristic features of entrepreneurial individuals. As a consequence, enterprises interested in innovative growth implement HRM practices in talent management which foster employees' entrepreneurship. The current paper presents results of a study conducted among 92 innovative Polish enterprises. The enterprises frequently created conditions facilitating the development of talented workers and their contribution to the innovative process. Relationships between the application of HRM practices in talent management and enterprises' innovation were observed in three aspects. There existed relationships between HRM practices in talent management and internal sources of innovation, effectiveness of the search and implementation of the innovative process, and the scale of novelty of implemented innovations.
\end{abstract}

Keywords: innovativeness, talent management, entrepreneurship, innovation.

Submitted: 23.10.17 | Accepted: 06.03.18

\section{Praktyki zarządzania talentami jako instrumenty stymulowania przedsiębiorczości pracowników}

Innowacyjność stanowi źródto uzyskania przewagi konkurencyjnej, dlatego przedsiębiorstwa sa zainteresowane poszukiwaniem innowacyjnych rozwiazań. Kluczowe znaczenie mają w tym pracownicy, a szczególnie ich przedsiębiorczość. Ponadto $w$ literaturze podkreślane jest znaczenie utalentowanych pracowników dla innowacyjności przedsiębiorstwa oraz można zauważyć, że sktadowe talentu wyraźnie koresponduja z charakterystykami jednostek przedsiębiorczych. Dlatego też przedsiębiorstwa zainteresowane innowacyjnym rozwojem wdrażaja praktyki $Z Z L$ w obszarze zarządzania talentami, które stymuluja przedsiębiorczość pracowników. W artykule przedstawiono wyniki badań przeprowadzonych w 92 polskich innowacyjnych przedsiębiorstwach. Wbadanych przedsiębiorstwach najczęściej tworzono sprzyjające warunki do rozwoju dla utalentowanych pracowników oraz wykorzystywano ich do innowacyjnego rozwoju. Zaobserwowano wystęujace zwiazki pomiędzy stosowaniem praktyk ZZL w obszarze zarzadzania talentami a innowacyjnościa przedsiębiorstwa rozpatrywang $w$ trzech aspektach. Istniaty zwiazki pomiędzy stosowanymi praktykami w obszarze zarzadzania talentami a wewnętrznymi źódłami innowacji, efektywnościa fazy poszukiwania $i$ wdrażania procesu innowacyjnego oraz skala nowości wdrożonych innowacji.

Aneta Karasek - PhD, Maria Curie-Skłodowska University in Lublin.

Correspondence address: Maria Curie-Skłodowska University in Lublin, Pl. M. Curie-Skłodowskiej 5, 20-031 Lublin; e-mail: aneta.karasek@umcs.pl. 
Słowa kluczowe: innowacyjność, zarządzanie talentami, przedsiębiorczość, innowacje.

Nadesłany: 23.10.17 | Zaakceptowany do druku: 06.03.18

JEL: M12, M50

\section{Introduction}

Dynamic changes emerging in the economy result in businesses facing a necessity of coping with new challenges. Therefore, the implementation of innovative solutions, the ones allowing expectations originating from the changing market to be satisfied, and competitive advantage achieved, seems critical from the enterprises' point of view. Innovation-based initiatives undertaken by businesses foster universal growth of economy to a greater degree than those aiming to imitate or satisfy typical, well-known needs (Glinka \& Gutkova, 2011).

Based upon the review of literature, the fact that innovative enterprises are influenced by both endogenous and exogenous factors can be observed. Innovation activity is determined by innovation capability of an enterprise. An organization with a culture that nurtures innovation and an organization supported by right people, the process will provide the path to create a broad diverse set of ideas, especially converting them into a profitable business concept (Rajapathirana \& Hui, 2018, pp. 44-55). According to Romanowska, the most critical, innovation-generating factors constitute the so-called innovation triad, which is composed of the following (Romanowska, 2015, p. 6):

- entrepreneurship (risk, management),

- creativity (creative teams and individuals),

- support systems (law, financing, education, science).

The author emphasizes the significance of entrepreneurship which impacts the generation of innovation. This fact was also confirmed by Bessant and Tidd (2011). Drucker and Schumpeter preceded them and indicated that innovation is inextricably linked with entrepreneurship. It is a multidimensional phenomenon and requires a diversified set of features depending upon various situational factors (Glinka \& Gutkova, 2011, p. 71). It is understood as a search for, as well as development and exploitation of, opportunities (Baran \& Bąk, 2016, pp. 83-98).
An important role in creating value is played by enterprise employees who enable an organization to implement value creating strategies and achieve a sustained competitive advantage. Capitalizing on existing knowledge vested in employees and collaborators as well as understanding and shaping the knowledge base of the innovation ecosystem, innovation intermediaries generate internal value from their involvement in collaborative innovation (Silvaa, Howells, \& Meyer, 2018, pp. 70-87). Talented employees are distinguished from other employees by the capital they possess, which enables them to make a difference and add value to their organizations (Sparrow \& Makram, 2015, pp. 250). Talented employees are both a valuable, rare, imperfectly imitable and non-substitutable asset and a resource that has the potential to contribute to value creation in an enterprise.

\section{Literature Review}

Enterprises aiming to boost their innovation may draw inspiration from various sources. However, innovations originating from internal sources are of particular importance. Studies conducted by $\mathrm{PwC}$ prove that $83 \%$ of innovations in enterprises were implemented on an internal initiative and merely $6 \%$ as a result of cooperation with clients (PricewaterhouseCoopers [PwC], 2016). Internal sources of innovation may be fueled via ideas offered by creative and talented employees of all levels and departments of the enterprise. These are usually less expensive than those purchased externally. In addition, even slight improvements offer synergies.

Innovation constitutes a process revolving around a proper application of resources and cooperation of employees possessing diverse competences. Therefore, the significance of the innovative process, which requires a series of diverse actions to be undertaken, and effective innovation management procedures to be introduced cannot be underrated. The enter- 
prise assesses its effectiveness in relation to actions associated with own and clients' expectations. The objective of the innovative process is to capture value (in the form of e.g. market success, improved market share, or reduced costs), which is visible in the form of patents or tacit knowledge (Tidd \& Bessant, 2011, p. 136). The capture occurs in the final stage of the process. The fact that not all implemented innovations bring expected outcomes is noteworthy. One of the significant outcomes of the innovative process is the scale of novelty of the implemented innovation due to the fact that it opens access to new markets.

Therefore, employees' entrepreneurship plays a considerable role in the innovation of enterprises. According to Bieniok (2016, p. 66), personal entrepreneurship constitutes a set of various positive features of character, and individual and group behaviors. We could recognize types of personalities that are more prone to be innovative. The study found a positive influence of extraversion, agreeableness, conscientiousness, and openness to experience on individual innovativeness and satisfaction with life perceptions (Amar \& Mullaney, 2017, pp. 494-501). On the other hand, entrepreneurial innovation expectedly benefits an individual's job satisfaction, balance between work and family, and life satisfaction (Wickstrøm Jensen, Liu, \& Schøtt, 2017, pp. 193-206).

Nowadays, the importance of social practices and processes that drive value creation and innovation is emphasized. There is a need to change institutions to be ready for a collaborative recombination of practices that provide novel solutions for new and existing problems (Vargo, Wieland, \& Akaka, 2015, pp. 63-72). During the implementation of radical innovations, entrepreneurs face the challenge of coordinating a complex network of actors in the presence of individual and collective uncertainties. Authors find collective experimentation, which demands a complex negotiation around value creation and value capture in cases of success and failure (Vasconcelos Gomes, Salernob, Phaalc, \& Probertc, 2018, 164-185). Enterprises need to stimulate their creativity and talents in order to boost innovativeness and see chances for implementing new solutions. Stauffer found the Value Creation Curve - a non-linear pattern that appears to characterize the relationship between personal innovativeness and entrepreneurial value creation (Stauffer, 2016, 4-26). This research confirms the role of innovativeness in creating value, demonstrates the utility of the Innovator Mindset assessment as a research instrument and provides a tool that entrepreneurs and investors can use to more accurately predict the likely outcomes of business ventures. An important role in creating value is played by innovation intermediaries who create internal value even though this is essential for ensuring their long-term survival and sustaining their key facilitating role in the innovation system (Silvaa, Howells, \& Meyer, 2018, 70-87). In light of the above, talented employees and their competences are significant for enterprises' innovation.

\section{Talent Management Practices}

The development of a knowledge-based economy has resulted in an increased demand for talented employees who are a factor in competitiveness (Buchelt, 2016, pp. 13-37). The literature recognizes the importance of talent for enterprises' innovation (Cascio \& Boudreau, 2016, pp. 103-114). Bock (2015, p. 118) highlights the importance of talented employees for the enterprise's success. Value resides in the unique set of knowledge, capabilities, contributions, commitment, skills, competencies and abilities possessed by an organization's talent (Sparrow \& Makram, 2015 , p. 250). It is them who achieve superior results and manifest vast development potential. On the other hand, Philips and Edwards (2009) observe that even the best idea or a project will not be implemented unless the enterprise has sufficiently talented employees at its disposal. Therefore, innovation of the enterprise pivots on talented workers.

Based upon the review of literature, various definitions of talent emerge. The understanding of the term depends upon organizational needs. The most popular publication on talent defines it as a sum of a person's abilities - their inborn gifts, skills, knowledge, experience, intelligence, beliefs, attitudes, personality, and entrepreneurship, as well as learning and selfimprovement skills (Michaels, HandfieldJones, \& Axelrod, 2001). The observation of talented employees revealed that they 
communicate with superiors and experts outside their workgroup regarding workrelated matters much more frequently. In addition, work allows them to make decisions more frequently (Sonnenberg \& Zijderveld, 2015, p. 48). This proves that the constituting elements of talent clearly correspond with characteristic features of entrepreneurial individuals. Therefore, entrepreneurship may be stimulated by the implementation of HRM practices targeting talented employees. According to Kacperczyk and Marx (2016, pp. 893-910), workers develop their entrepreneurship when conducting their duties. Owing to their skills, talented workers are able to achieve superior results and create novel solutions provided that suitable conditions are offered. Therefore, talent management is defined as the philosophy of triggering dormant reserves accumulated in employees who have not been relied upon previously (Bieniok, 2008, p. 413).

At present, due to the dynamic character of their surrounding environment, enterprises must be flexible when adjusting to diverse and ever-changing requirements of clients, employees, and a long-term perspective for achieving results. As a consequence, enterprises focus upon knowledge and skills of staff and upon the retention of employees whose skills are irreplaceable (Stone \& Deadrick, 2015, p. 140). Workers contribute knowledge, skills and experience which surpass the requirements of their positions. Employees increasingly select such workplaces which offer to satisfy their needs and passions and enable their development. As a consequence, a discussion regarding means of influencing employees via HRM practices emerged. The application of such practices aims to shape desired workers' behaviors (Wright \& Nishii, 2013, p. 14). In addition, HRM facilitates the achievement of a required change in employees' attitudes (Boselie, Dietz, \& Boon, 2005). Employees covered by HRM practices are able to become familiar with their diverse competences and shape suitable behaviors and attitudes. Enterprises implement different sets of talent management practices but the most often highlighted feature is the size of the enterprise. The institutional context is different for large and SMEs because the identification of strategic jobs and developing high potentials are more important in multinational companies (Krishnan \& Scullion, 2017, pp. 431-441). In Polish enterprises, there are also differences in talent management programs which were analyzed by Pocztowski (Pocztowski, 2016, pp. 183-186).

The development of an employeremployees relationship is significant due to the fact that talented workers set their own objectives, which may constitute success factors for the enterprise (Miś, 2016, pp. 239). Employers indicate which behaviors are expected of workers via HRM practices. This facilitates workers undertaking new and unorthodox activities. On the other hand, as a result of HRM practices, employees may become project managers and implement solutions, and achieve group recognition, which may satisfy their needs.

The review of literature indicates that HRM practices exert a direct influence upon enterprises' innovation (e.g. Zhou, Hong, \& Liu, 2013; Arvanitis, Seliger, \& Stucki, 2016). As a consequence, HRM practices which will involve employees in the innovative process are required. Glinka and Gutkova (2011, p. 227) observe that cohesive HRM practices simplify management in enterprises. However, their main drawback is the possibility that employees who may offer the enterprise an innovative potential will not be selected. As a consequence, practices which address talented workers ought to be focused upon as these will stimulate employees' entrepreneurship.

Talent management encompasses several aspects and stages: starting with attracting employees to the organization, employees' development, assessment of their results, and finally, retaining them in the organization. The identification of talented workers constitutes an initial stage. HRM practices addressing the pursuit of such workers internally within the enterprise and in its surrounding environment, and then attracting them to the structure, are applied in this case. The pool of present workers may include talents who may not have had an opportunity to discover and apply their competences. In order to detect them, a review of employees' performance and activity is conducted daily by means of a monitoring system. Such an approach offers information on employees' efficiency (Chamorro-Premuzic, 2015). Google organizes 24h "FixIts", which require employees to solve a particular problem 
(He, 2013). As a consequence, particular knowledge on competences of individual employees is acquired. In addition, employees themselves are able to achieve selffulfillment. Moreover, the idea box is also applied. Employees may offer novel and unorthodox solutions and drop them into the box. Talented workers may be identified in this way as well.

Enterprises' changing requirements stimulate the pursuit of employees possessing competences that are missing in the enterprise at the particular time. The search is conducted by means of social recruitment among group members in social media, online specialist fora and by crowdsourcing. On the other hand, the pursuit of young talents to fill positions in R\&D departments is conducted at universities (Petroni, Venturini, \& Verbano, 2012, p.171). Enterprises organize intensive trainings and offer mentoring to such candidates (Dhawan, 2016).

In order to attract talented employees, the development of suitable conditions which will encourage them to work is required. As a consequence, understanding employees' behaviors is significant in order to develop suitable recruitment strategies. Prior to talented employees commencing work, the following organizational aspects of the enterprise are analyzed: autonomy, support when taking risk, ability to cooperate and share knowledge with other talented and passionate employees, financial and non-financial incentives, and public awards for creative results (Hunter, Cushenbery, \& Friedrich, 2012, pp. 303-322). In addition, work-life balance is significant. When the balance is achieved, employees are able to pursue their passions and broaden their horizons.

A mere recognition of the fact that talented employees are important to the enterprise is not sufficient. Suitable development opportunities for them must be ensured. It was observed that employees of HRM departments focus upon the search for means of boosting the development of talented workers by offering experienceimproving opportunities (Meister and Willyerd, 2010, p. 253). Employees ought to be encouraged to cooperate intelligently. In addition, benefits of such cooperation should be clearly indicated because many employees prefer to achieve success independently (Gardner, 2017, pp. 100-108).
Moreover, access to formal and informal knowledge ought to be ensured, and so should be the opportunity for sharing knowledge. When planning developmentrelated actions, it is necessary to take into account the needs of talented workers. Favorable conditions enabling employees to develop and pursue their objectives, and not be overburdened at the same time, ought to be offered. In addition, individual approach to employees, the one where the employer offers development opportunities unavailable to other workers, is significant. It was observed that many successful enterprises are able to attract and retain talents by offering financial incentives more seldom than their competition. Instead, they enable employees to develop their potential and exploit personal interests (Lash, 2016). When employees are offered a greater degree of independence, they are able to utilize their creative potential.

The involvement of talented employees in the innovative process constitutes a challenge for innovative enterprises. According to Bock (2015, p. 67), blind employment of high-potential workers and allowing them to do as they please present a recipe for a disaster. Employees ought to be challenged with objectives and tasks to be fulfilled. This constitutes a chance for novel solutions to emerge. They also ought to be matched with suitable positions. In addition, networks of relations between talented employees should be developed. Skills development, involvement and adjustment of employees are fostered in this way. Remaining workers usually orbit around those distinguishing themselves, achieving best results or working with passion (Schmidt \& Rosenberg, 2014, p. 47). As a consequence, information advantage accompanied with a high level of social capital is developed (Oldroyd \& Morris, 2012, pp. 396-418). In light of the above, mechanisms allowing talented workers to be used in order for the enterprise's objectives to be achieved, ought to be created.

In conclusion, it is necessary to highlight that talented workers play a significant role in enterprises, especially with regard to the generation of innovative solutions. HRM practices associated with talent management should be introduced. These should match the context of the enterprise because they shape the 
way stakeholders perceive and respond to the organizational stimulation. Talented workers ought to be covered by dedicated HRM practices. Otherwise, it may hinder the innovative growth of the enterprise. Cascio and Boudreau (2016, pp. 103-114) observe that the incorporation of talent management into HRM practices constitutes a challenge for enterprises. Glinka and Gutkova (2011, p. 231) and Tabor (2013, p. 65) observed a diversity regarding the frequency of the application of such practices in Polish enterprises. Other studies indicate a diversification in local and international businesses, with comprehensive and thought-through practices found in the latter (Tatoglu, Glaister, \& Demirbag, 2016, pp. 278-293).

\section{Data and Methodology}

Due to the acknowledged significance of HRM practices regarding talent management and their impact upon innovation of enterprises, relationships emerging between the two fields are worth examining. The objective of the present study was to identify HRM practices applied in Polish innovative enterprises and their relationship with the enterprises' innovation.

Research suggests that there are several aspects of innovativeness of enterprises. However, the literature emphasizes the particular importance of the sources of innovation, including in particular those coming from creative and talented employees as well as the enterprise management. It seems important to examine the relationship between the applied HRM practices and the internal sources of innovation. Hence, the following hypothesis was formulated:

H1: There is a relationship between HRM practices regarding talent management and internal sources of innovation.

H1.1. There is a relationship between HRM practices regarding talent management and innovations originating from creative, talented employees.

H1.2. There is a relationship between $H R M$ practices regarding talent management and innovations originating from the enterprise management.

The implementation of innovative ideas requires an effective implementation of individual phases of the innovation process, for which talented employees are neces- sary. In the research model, it was assumed that we could distinguish the following phases in the innovative process: searching, selection, implementation and capture (Tidd and Bessant, 2011, p. 128). Its effectiveness is understood as the ratio of effects produced to expenditures incurred (Michna \& Czerwińska-Lubszczyk, 2016, p. 250). In the context of HRM practices used in an innovative enterprise, it seems interesting to examine their relationship with the effectiveness of the phases of the innovation process. This allowed us to formulate the second hypothesis and partial hypotheses.

H2: There is a relationship between HRM practices regarding talent management and the effectiveness of innovation process phases.

H2.1. There is a relationship between $H R M$ practices regarding talent management and the effectiveness of the searching phase of the innovation process.

H2.2. There is a relationship between $H R M$ practices regarding talent management and the effectiveness of the selection phase of the innovation process.

H2.3. There is a relationship between HRM practices regarding talent management and the effectiveness of the implementation phase of the innovation process.

H2.4. There is a relationship between HRM practices regarding talent management and the effectiveness of the capture phase of the innovation process.

The result of the innovation process is a new solution that can be assessed in terms of the scale of novelty of the implemented innovation (global, domestic, enterprise). It becomes necessary to examine if there is a relationship between HRM practices applied in an enterprise and the scale of implemented innovations. This allowed the formulation of the third hypothesis:

H3: There is a relationship between HRM practices regarding talent management and the scale of novelty of implemented innovations.

To analyze the prior hypotheses, an empirical survey needs to be carried out. The study was conducted in small, medium and large innovative enterprises operating in Poland. In accordance with OSLO methodology (Organisation for Economic Co-operation and Development [OECD] \& Eurostat, 2006, p. 49), an assumption was made that an innovative enterprise is 
the one which implemented at least one product, process, or organizational or marketing innovation. It was assumed that the implementation period of the innovation was two years. The study with the use of a questionnaire ran between October 2015 and June 2016 and was conducted among managers responsible for human resources management in an enterprise. Ninety two completed questionnaires were returned. The sample was dominated by small enterprises $(52.2 \%)$. Next, medium-sized enterprises constituted $25.1 \%$ and large ones $20.7 \%$ of the sample.

Based upon the review of literature, HRM practices regarding talent management were identified. The present study requested respondents to assess specific HRM practices in talent management:

- identification of talented employees within the organization,
- identification and attraction of talented people in the environment,

- effective involvement of talented employees in innovative growth,

- offering favorable conditions that facilitate the development of talented employees.

A variable constituting an average value of answers for HRM practices applied was developed on the basis of HRM practices regarding talent management. In order to verify the reliability of the selection, Cronbach's alpha was calculated. The coefficient amounted to 0.78 .

\section{Research Results}

The frequency of the use of HRM practices regarding talent management was assessed in the studied innovative enterprises.

Figure 1. HRM practices regarding talent management in the studied enterprises (median)

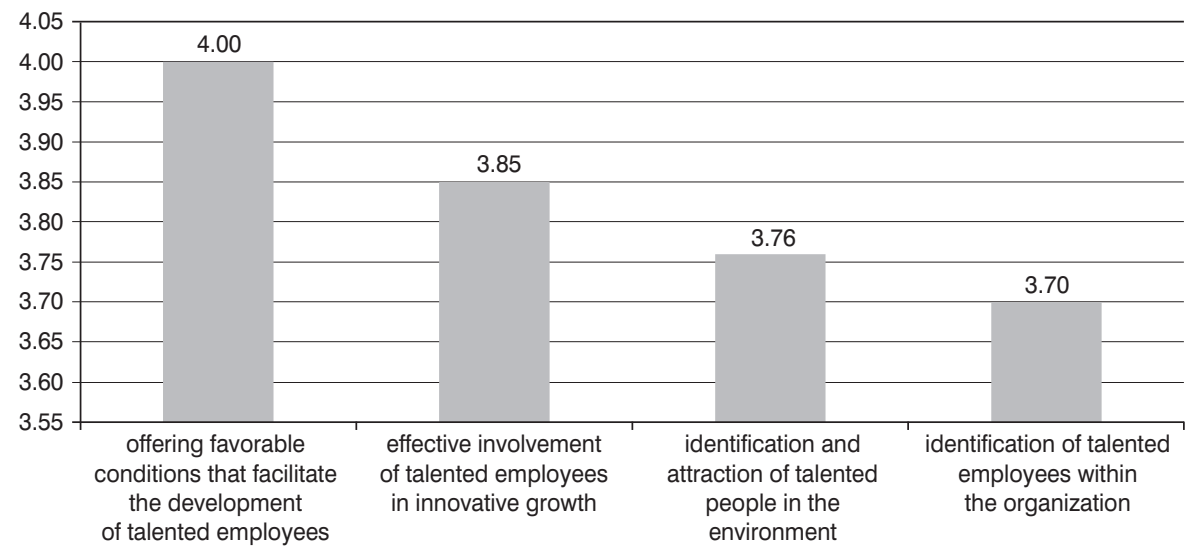

Source: author's own study based upon quantitative data.

The studied innovative enterprises (Figure 1) frequently offered favorable conditions facilitating the development of talented employees $(\mathrm{Me}=4.00)$. This fact may prove that these organizations recognized the benefits of ensuring such conditions for the group. Respondents indicated that talented employees were effectively involved in an innovative growth $(\mathrm{Me}=3.85)$, which proves that their contribution to innovative processes was beneficial for the enterprise. On the other hand, the studied enterprises were not as successful regarding the identification and attrac- tion of talented people in the environment $(\mathrm{Me}=3.76)$ and the identification of talented employees within the organization $(\mathrm{Me}=3.70)$. When analyzing the obtained results, it can be observed that growth conditions facilitating the development of talented workers and their contribution to innovative growth are more typical of the studied enterprises than the identification of talents internally and externally.

Subsequently, relationships between HRM practices regarding talent management and enterprises' innovation were analyzed in the following three aspects: inter- 
nal sources of innovation, effectiveness of innovation process phases, and the scale of novelty of implemented innovations. Spearman's rank correlation coefficient was applied in the process.
Relationships between HRM practices and internal sources of innovation were analyzed as first. An assumption was made that these sources encompass creative, talented employees and the management.

Table 1. Correlations between HRM practices in HRM and internal sources of innovation, including those originating from creative, talented employees and the management in the studied enterprises

\begin{tabular}{|l|c|c|}
\cline { 2 - 3 } \multicolumn{1}{c|}{} & \multicolumn{2}{c|}{ HRM practices in talent management } \\
\cline { 2 - 3 } \multicolumn{1}{c|}{} & $\boldsymbol{r}_{\boldsymbol{s}}$ & $\boldsymbol{p}$ \\
\hline Internal sources of innovation: & $.459^{* *}$ & 0.001 \\
\hline - creative, talented employees & $.439^{* *}$ & 0.001 \\
\hline - the management & $.348^{* *}$ & 0.001 \\
\hline
\end{tabular}

*** Correlation is significant at the 0.01 level (two-tailed).

Source: author's own study on the basis of quantitative data.

On the basis of research results (Table 1), it can be observed that positive and statistically relevant correlations emerge between the internal sources of innovation and HRM practices regarding talent management. It can be said that the more frequently HRM practices in talent management are applied, the more innovations originate from internal sources. Therefore, it can be observed that positive and statistically relevant correlations emerge between creative, talented employees and the management constituting the internal source of innovation, and
HRM practices regarding talent management. The strongest relationship occurs between creative, talented workers and HRM practices in talent management. It can be said that the more frequently HRM practices in talent management are applied, the more innovations originate from creative, talented employees. The obtained results allow us to accept the first hypothesis.

The second innovative aspect was the effectiveness of the innovative process conducted by businesses in relation to own and clients' expectations.

Table 2. Correlation between HRM practices in particular HRM areas and the effectiveness of the course of the innovative process in the studied enterprises

\begin{tabular}{|l|c|c|c|c|c|c|c|c|}
\cline { 2 - 9 } \multicolumn{1}{c|}{} & \multicolumn{9}{c|}{ Effectiveness of the innovative process: } \\
\cline { 2 - 9 } \multicolumn{1}{c|}{ Search } & \multicolumn{2}{c|}{ Selection } & \multicolumn{2}{c|}{ Implementation } & \multicolumn{2}{c|}{ Capture } \\
\cline { 2 - 9 } & $\boldsymbol{r}_{\boldsymbol{s}}$ & $\boldsymbol{p}$ & $\boldsymbol{r}_{\boldsymbol{s}}$ & $\boldsymbol{p}$ & $\boldsymbol{r}_{\boldsymbol{s}}$ & $\boldsymbol{P}$ & $\boldsymbol{r}_{\boldsymbol{s}}$ & $\boldsymbol{p}$ \\
\hline $\begin{array}{l}\text { HRM practices } \\
\text { in talent management }\end{array}$ & $.233^{*}$ & .025 & .203 & .053 & $.232^{*}$ & .026 & .171 & .104 \\
\hline
\end{tabular}

\footnotetext{
** Correlation is significant at the 0.01 level (two-tailed).
}

* Correlation is significant at the 0.05 level (two-tailed).

Source: author's own study on the basis of quantitative data.

On the basis of research results (Table 2), it can be established that there exist positive and statistically significant correlations between HRM practices in talent management and the effectiveness of searching for and implementing the innovative process. Therefore, the more frequently HRM practices in talent management were introduced, the more effective the search for innovationrelated opportunities and the implementation of innovative solutions were. The second hypothesis has been partially confirmed. 
Outcomes of innovative actions in an enterprise may be assessed by means of the scale of novelty of implemented innovations. Relationships between HRM practices and the scale of implemented solutions were evaluated. A moderate correlation exists between HRM practices in talent management and the novelty of innovative solutions $\left(r_{s}=0.435 ; p=0.001\right)$. Therefore, the more frequently HRM practices in talent management were applied, the greater the novelty of innovations was. The obtained results allow us to accept the third hypothesis.

\section{Conclusions}

Innovative growth of enterprises requires the involvement of employees whose competences enable innovative solutions to be developed. As a consequence, employees must be stimulated so that they recognize more opportunities for the emergence of innovative solutions and are able to act upon them. Talented employees are critical in this respect from the point of view of innovative processes. Behaviors expected of them ought to be clearly indicated. In light of the above, enterprises search for methods for stimulating the entrepreneurship of employees, especially talented ones.

Studies indicate that innovative enterprises apply HRM practices which impact employees' behaviors. The fact that HRM practices in talent management have been frequently introduced in Polish businesses is positive. Frequent development of conditions facilitating the development of talented employees and their contribution to innovative growth is characteristic of these enterprises. The identification of such employees internally and externally occurs more rarely. This proves that enterprises recognized benefits of ensuring suitable conditions for this particular group. In addition, the fact that the group's share in innovative processes was beneficial for enterprises was also acknowledged.

It can be observed on the basis of the current study that relationships between HRM practices in talent management and enterprises' innovation were present in the studied enterprises. The more frequently HRM practices in talent management were applied, the more innovations originated from internal sources, the more effective was the search for innovations and their implementation, and the greater was the scale of novelty of innovative solutions.

In conclusion, talented workers whose knowledge and skills contribute to the achievement of superior results, and who possess suitable growth potential, are critical from the perspective of enterprises' innovation. As a result of the implementation of talent management practices, their entrepreneurship is stimulated. Moreover, it leads to the stimulation of employee creativity and an increase of their innovative behavior. This, in turn, translates into novel solutions, organizational performance and getting competitive advantage.

\section{References}

Amar, A.D. \& Mullaney, K. (2017). Employee ability to innovate: How can organizations recognize it. Procedia Computer Science, 122, 494-501.

Arvanitis, S., Seliger, F., \& Stucki, T. (2016). The relative importance of human resource management practices for innovation. Economics of Innovation and New Technology, 25(8), 769-800.

Baran, G. \& Bąk, J. (2016). Przedsiębiorczość jako proces stawania się. In M. Kosała, M. Urbaniec, \& A. Żur (Eds.), Współczesne dylematy badań nad przedsiębiorczością. Przedsiębiorczość Międzynarodowa, 2(1), 83-98.

Bessant, J. \& Tidd, J. (2015). Innovation and Entrepreneurship (3rd ed.). Wiley.

Bieniok, H. (2008). Zarządzanie talentami jako źródło wiedzy i kompetencji organizacji. In A. Glińska-Neweś (Ed.), Zarzadzanie organizacjami $w$ gospodarce opartej na wiedzy. Zasobowe podstawy funkcjonowania i rozwoju organizacji. Toruń: TNOiK, Dom Organizatora.

Bieniok, H. (2016). Istota przedsiębiorczości osobistej w kontekście zarządzania samym sobą. In M. Kosała, M. Urbaniec, \& A. Żur (Eds.), Współczesne dylematy badań nad przedsiębiorczością. Przedsiębiorczość Międzynarodowa, 2(1) 65-82.

Bock, L. (2015). Work rules! Insights from inside Google that will transform how you live and lead. New York: Twelve.

Boselie, P., Dietz, G., \& and Boon, C. (2005). Commonalities and contradictions in HRM and performance research. Human Resource Management Journal, 15(3).

Buchelt, B.I. (2016). Rosnace znaczenie talentów w gospodarce. In A. Pocztowski, Zarzadzanie talentami $w$ organizacji (pp. 13-37) (2nd rev. ed.). Warszawa: Wolters Kluwer.

Cascio, W.F. \& Boudreau, J.W. (2016). The search for global competence: From international HR 
to talent management. Journal of World Business, 51(1), 103-114.

Chamorro-Premuzic, T. (2015). 3 emerging alternatives to traditional hiring methods. Retrieved from https://hbr.org/2015/06/3-emerging-alternatives-totraditional-hiring-methods

De Silva, M., Howells, J., \& Meyer, M. (2018) Innovation intermediaries and collaboration: Knowledge-based practices and internal value creation. Research Policy, 47(1), 70-87.

Dhawan, E. (2016). Recruiting strategies for a tight talent market. Harvard Business Review. Retrieved from https://hbr.org/2016/04/recruiting-strategiesfor-a-tight-talent-market\&ab=Article-Links-End of_Page_Recirculation

Gardner, H.K. (2017). Getting your stars to collaborate. Harvard Business Review, 95(1), 100-108.

Glinka, B. \& Gutkova, S. (2011). Przedsiębiorczość. Warszawa: Oficyna a Wolters Kluwer business.

He, L. (2013). Google's secrets of innovation: Empowering its employees. Retrieved from http:// www.forbes.com/sites/laurahe/2013/03/29/googlessecrets-of-innovation-empowering-its-employees/ \#13ba8e887eb3

Hunter, S.T., Cushenbery, L., \& Friedrich, T. (2012). Hiring an innovative workforce: A necessary yet uniquely challenging endeavor. Human Resource Management Review, 22(4), 303-322.

Kacperczyk, A. \& Marx, M. (2016). Revisiting the small-firm effect on entrepreneurship: Evidence from firm dissolutions. Organization Science, 27(4), 893-910.

Krishnan, T.N. \& Scullion, H. (2017). Talent management and dynamic view of talent in small and medium enterprises. Human Resource Management Review, 27(3), 431-441.

Lash, R. (2016). Być liderem dzięki innowacjom. Retrieved from https://www.hbrp.pl/b/byc-lideremdzieki-innowacjom/cIx0xvVo

Meister, J.C. \& Willyerd, K. (2010). The 2020 workplace. How innovative companies attract, develop, and keep tomorrow's employees today. Harper Business.

Michaels, E., Handfield-Jones, H., \& Axelrod, B (2001). The war for talent. Boston: Harvard Businesss School Press. As cited in J.A. Tabor, (2013) Zarzadzanie talentami $w$ przedsiębiorstwie. Koncepcje, strategie, praktyka. Warszawa: Poltext.

Michna, A. \& Czerwińska-Lubszczyk, A. (2016) Złożoność wielowymiarowego pomiaru efektywności funkcjonowania przedsiębiorstw - przyczynek do dalszych badan. Systemy Wspomagania w Inżynierii Produkcji, 1(13).

Miś, A. (2016). Rozważania teoretyczne nad istota talentu i ich konsekwencje dla zarządzania talentam. Zarzadzanie $i$ Finanse. Journal of Management and Finance, 14(2/1).
Oldroyd, J.B. \& Morris, S.S. (2012). Catching falling stars: A human resource response to social capital's detrimental effect of information overload on star employees. Academy of Management Review, 37.

Organisation for Economic Co-operation and Development \& Eurostat. (2006). Podręcznik Oslo. Zasady gromadzenia i interpretacji danych dotyczacych innowacji $\left(3^{\text {rd }}\right.$ ed.). Warszawa: Ministerstwo Nauki i Szkolnictwa Wyższego, Departament Strategii i Rozwoju Nauki.

Petroni, G., Venturini, K., \& Verbano C. (2012). Open innovation and new issues in $\mathrm{R} \& \mathrm{D}$ organization and personnel management. International Journal of Human Resource Management, 23(1).

Philips, J.J. \& Edwards, L. (2009). Managing talent retention: An ROI approach. San Francisco: John Wiley \& Sons.

Pocztowski, A. (2016). Programy zarządzania talentami. In A. Pocztowski, Zarzadzanie talentam w organizacji (2nd rev. ed.) (pp. 183-186). Wolters Kluwer.

PricewaterhouseCoopers. (2016). Przywództwo przyszłości. Polski lider gotowy na zmiane? Retrieved from http://www.pwc.pl/pl/publikacje/2016/liderprzyszlosci.html

Rajapathirana, R.P.J. \& Hui, Y. (2018). Relationship between innovation capability, innovation type, and firm performance. Journal of Innovation \& Knowledge, 3(1), 44-55.

Romanowska, M. (2015). Innowacyjne przedsiebiorstwo w nieinnowacyjnej gospodarce. Przeglad Organizacji, (8), 4-8.

Schmidt, E. \& Rosenberg, J. (2014). How Google works. John Murray.

Sonnenberg, M. \& van Zijderveld, V. (2015). Realizing the highest value of investments in talent management. In M. Andresen \& C. Nowak (Eds.), Human resource management practices, assessing added value. Springer.

Sparrow, P.R. \& Makram H. (2015). What is the value of talent management? Building value-driven processes within a talent management architecture Human Resource Management Review, 25, 249-263.

Stauffer, D. (2016). Personal innovativeness as a predictor of entrepreneurial value creation, International Journal of Innovation Science, 8(1), 4-26.

Stone, D.L. \& Deadrick, D.L. (2015). Challenges and opportunities affecting the future of human resource management. Human Resource Management Review, 25.

Tabor, J.A. (2013). Zarzadzanie talentami w przedsiębiorstwie, koncepcje, strategie, praktyka. Warszawa: Poltext.

Tatoglu, E., Glaister, A.J., \& Demirbag, M. (2016). Talent management motives and practices in an 
emerging market: A comparison between MNEs and local firms. Journal of World Business, 51(2).

Tidd, J. \& Bessant, J. (2011). Zarzadzanie innowacjami. Integracja zmian technologicznych, rynkowych $i$ organizacyjnych. Warszawa: Oficyna a Wolters Kluwer business.

Vargo, S.L., Wieland, H., \& Akaka, M.A. (2015) Innovation through institutionalization: A service ecosystems perspective. Industrial Marketing Management, 44, 63-72.

Vasconcelos Gomes, A.V., Salernob, M.S. Phaalc, R., \& Probertc, D.R. (2018). How entrepreneurs manage collective uncertainties in innovation ecosystems. Technological Forecasting \& Social Change, 128(C), 164-185.
Wickstrøm Jensen, K., Liu, Y., \& Schøtt, T. (2017). Entrepreneurs innovation bringing job satisfaction, work-family balance, and life satisfaction. International Journal of Innovation Studies, 1(4), 193-206.

Wright, P.M. \& Nishii, L.H. (2013). Strategic HRM and organizational behaviour: Integrating multiple levels of analysis. In D. Guest, J. Paauwe, \& P. Wright (Eds.), Human resource management and performance: Progress and prospects. Oxford: Wiley-Blackwell.

Zhou, Y., Hong, Y., \& Liu, J. (2013). Internal commitment or external collaboration? The impact of human resource management systems on firm innovation and performance. Human Resource Management, 52, 263-288. 